\title{
OPEN
}

\section{Author Correction: A monocyte gene expression signature in the early clinical course of Parkinson's disease}

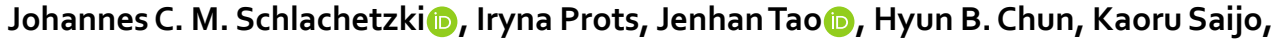 \\ David Gosselin, Beate Winner, Christopher K. Glass \& Jürgen Winkler
}

Correction to: Scientific Reports https://doi.org/10.1038/s41598-018-28986-7, published online 17 July 2018

This Article contains an error in the Acknowledgements section, where

"Sequencing datasets generated for this study have been submitted to Gene Expression Omnibus (GEO) repository (accession number GSE888888)."

should read:

"Sequencing datasets generated for this study have been submitted to Gene Expression Omnibus (GEO) repository (accession number GSE88888)."

(c) (i) Open Access This article is licensed under a Creative Commons Attribution 4.0 International License, which permits use, sharing, adaptation, distribution and reproduction in any medium or format, as long as you give appropriate credit to the original author(s) and the source, provide a link to the Creative Commons license, and indicate if changes were made. The images or other third party material in this article are included in the article's Creative Commons license, unless indicated otherwise in a credit line to the material. If material is not included in the article's Creative Commons license and your intended use is not permitted by statutory regulation or exceeds the permitted use, you will need to obtain permission directly from the copyright holder. To view a copy of this license, visit http://creativecommons.org/licenses/by/4.0/.

(C) The Author(s) 2020 